\title{
Stratified Condition of Lake Kaiike, a Small Coastal \\ Lake on Kamikoshiki Island, Kagoshima Prefecture
}

\author{
Michiro Matsuyama
}

\begin{abstract}
Vertical distributions of chlorinity, water temperature, dissolved oxygen and hydrogen sulfide have been obtained from Lake Kaiike, a small coastal lake on Kamikoshiki Island, Kagoshima Prefecture, during April, 1976 and October, 1977. Lake Kaiike (surface area: $0.15 \mathrm{~km}^{2}$; maximum depth: $11.6 \mathrm{~m}$ ) is stratified between brackish water layer above (chlorinity, 6.6-12.2\%) and saline layer below (chlorinity, more than $17 \%$ ). During the spring and autumn, high temperature of up to $39^{\circ} \mathrm{C}$ were found in the boundary. In the lower water layer an anoxic condition prevailed throughout the year and a noticeable amount of hydrogen sulfide was contained. From autumn to winter the lake was exposed to wind-induced mixing process and the stratified condition was somewhat altered. With the gradual rise of sea level during spring to summer seawater intruded into the bottom by seepage through the gravel bar.
\end{abstract}

\section{Introduction}

Lake Kaiike and neighboring two lakes on the north shore of Kamikoshiki Island, which are all separated from the sea only by narrow gravel bars (Fig. 1), were studied in detail by the KOBE MARINE OBSERVATORY in 1934 and 1938 (KoBE MARINe ObSERVATORY, 1935, 1941). L:mnological characteristics of Lake Kaiike such as a marked stratified condition of upper brackish water layer overlying saline layer, unusually high temperature at the subsurface depth and a noticeable amount of hydrogen sulfide in the lower layer attracted the attention of some investigators. But no study had been made on these lakes for a long period. ARAMAKI et al. (1976) made detailed studies on hydrological features of these lakes with reference to geomorphological characteristics of the gravel bars. MATSUYAMA (1977) undertook a limnological research on Lake Kaiike. He showed that the lower saline water in the lake originated from seawater which entered the bottom by seepage through the gravel bar; after staying for some time, it

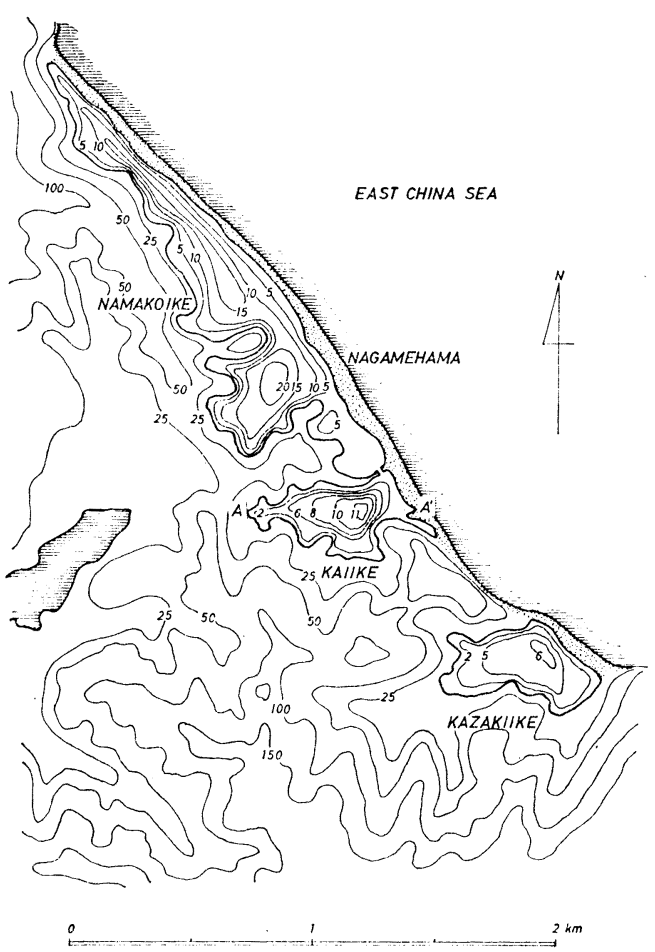

Fig. 1. Lake Kaiike and neighboring two lakes, Namakoike and Kazakiike. These lakes are separated from the sea by the gravel bar called "Nagamehama". Depth and height are in meter. 
was carried to the surface by mixing and then to an adjacent lake, Namakoike.

The purpose of the present paper is to report the stratified condition of Lake Kaiike from the vertical distributions of chlorinity and temperature in the lake which were obtained during April, 1976 and October, 1977.

\section{Methods}

Sampling was done at a central point of the lake by using a Van Dorn or Kitahara sampler. Water temperature was measured with a guaranteed glass thermometer as samples were taken from various depths. Chlorinity was measured by the MohrKnudsen method in the laboratory. Dissolved oxygen content was measured by the
Winkler titration method. Hydrogen sulfide content was measured by the iodometric titration of $\mathrm{CdS}$ precipitate which was formed by adding $\mathrm{CdCO}_{3}$ suspension into sample water (American Public Health Association, 1965).

\section{Results}

\section{Chlorinity}

Figure 2 shows the vertical distribution of chlorinity in Lake Kaiike during the period from April, 1976 to October, 1977. Chlorinity of surface water showed a seasonal variation from 6.58 to $12.25 \%$. From 1-3 $\mathrm{m}$ depth it increased rapidly and reached $17 \%$ at $5 \mathrm{~m}$. Chlorinity of bottom water was between $18.38-18.88 \%$. A seasonal change in the monthly mean sea level
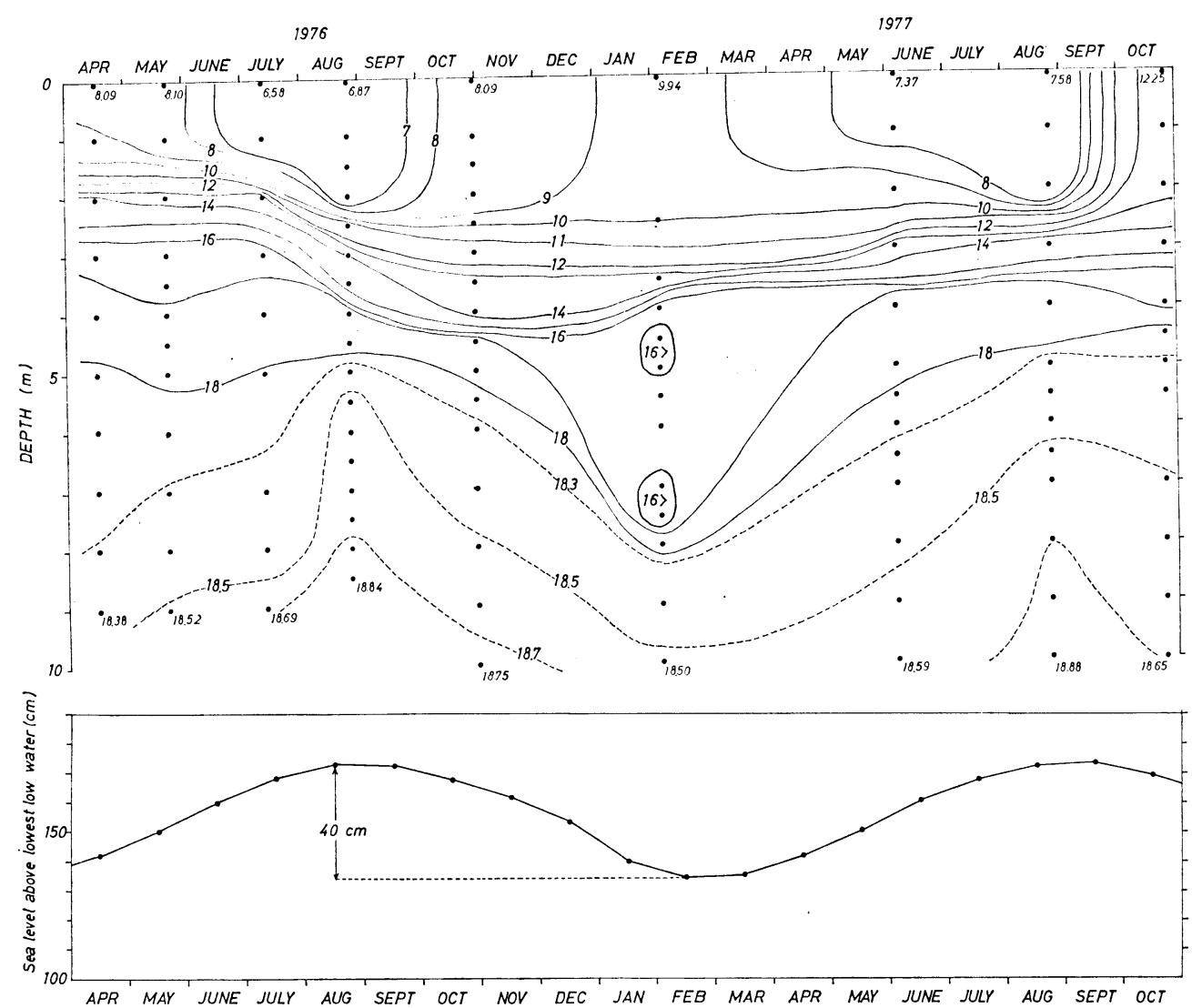

Fig. 2. Vertical distribution of chlorinity in Lake Kaiike during the period, April, 1976 and October, 1977, with seasonal variation of sea level at Kamikoshiki Island predicted by Maritime Safety Agency of Japan (1976, 1977). 
at Kamikoshiki Island is also given in Figure 2 (Maritime Safety Agency of JAPAN, 1976, 1977). Figure 3 shows the distribution of chlorinity in a cross section from the west end of the lake to the gravel bar (from point $A$ to point $A^{\prime}$ in Fig. 1) in October, 1976. There was a sharp chlorinity gradient at the depth of 3-5 m throughout the lake.

\section{Temperature}

Vertical distribution of temperature in Lake Kaiike is shown in Figure 4. The high temperature was always found at 3-4 m depth during spring to autumn. At $3 \mathrm{~m}$ depth in August, 1976 temperature as high as $39^{\circ} \mathrm{C}$ was observed and it decreased below $3 \mathrm{~m}$ depth. Bottom water temperature was about $19-22^{\circ} \mathrm{C}$ through the year. Figure 5 shows the distribution of temperature in the same cross section as shown in Figure 3. A high temperature zone extended as a discrete band at the same depth as the halocline in the lake.

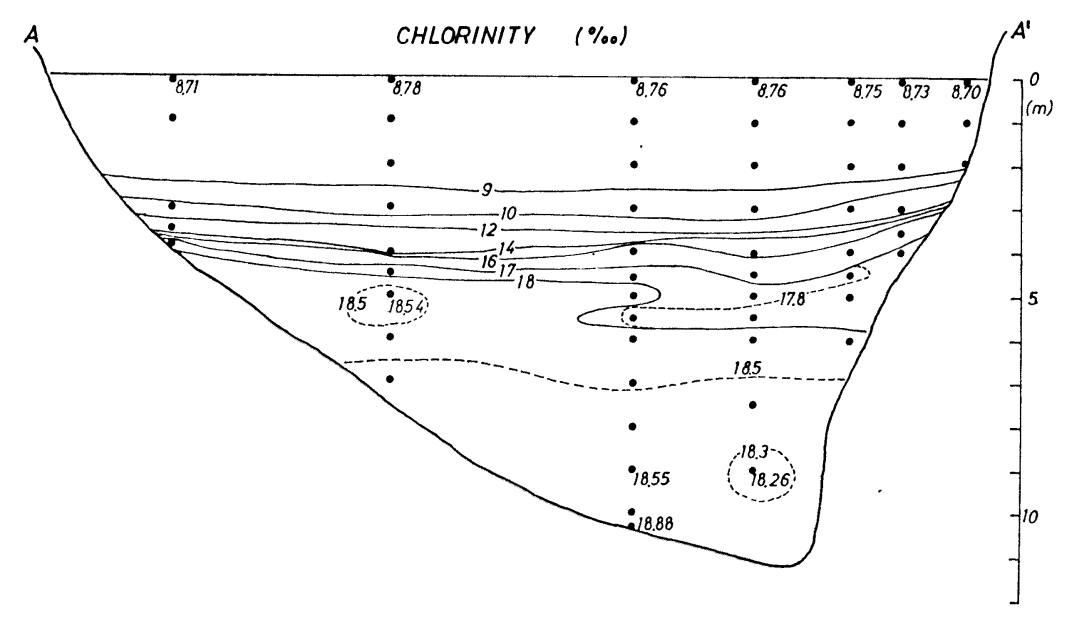

Fig. 3. Distribution of chlorinity in the cross section of Lake Kaiike from the west end (A in Fig. 1) to the gravel bar $\left(\mathrm{A}^{\prime}\right)$ on 29 October, 1976.

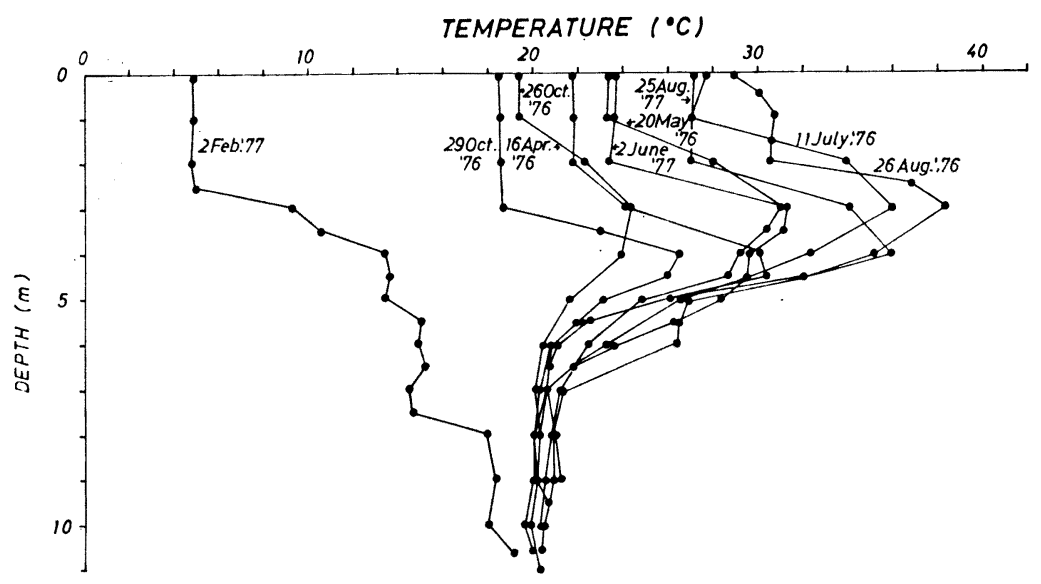

Fig. 4. Vertical distribution of temperature in Lake Kaiike during the period, April, 1976 and October, 1977. 


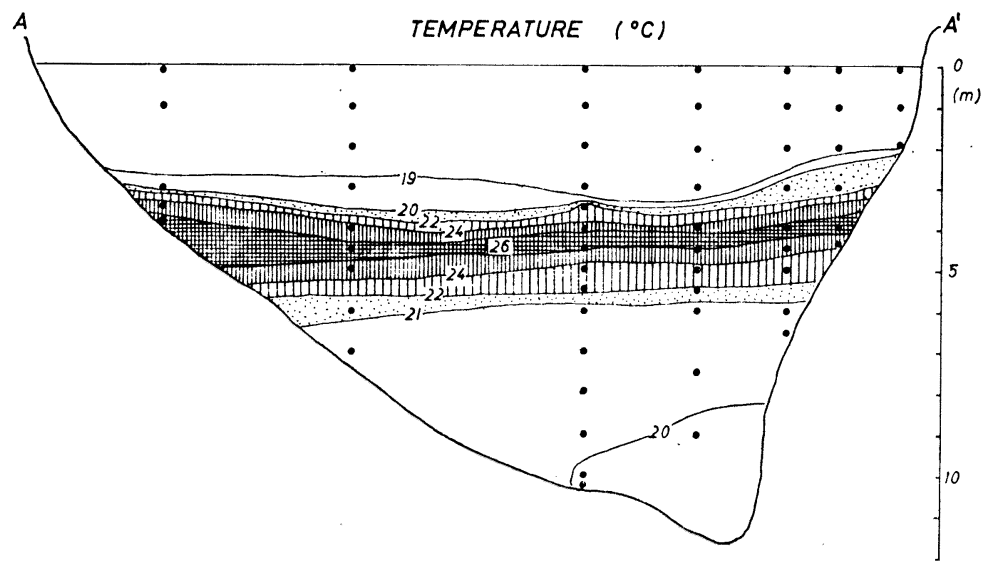

Fig. 5. Distribution of temperature in the cross section of Lake Kaiike shown in Fig. 3 on 29 October, 1976.

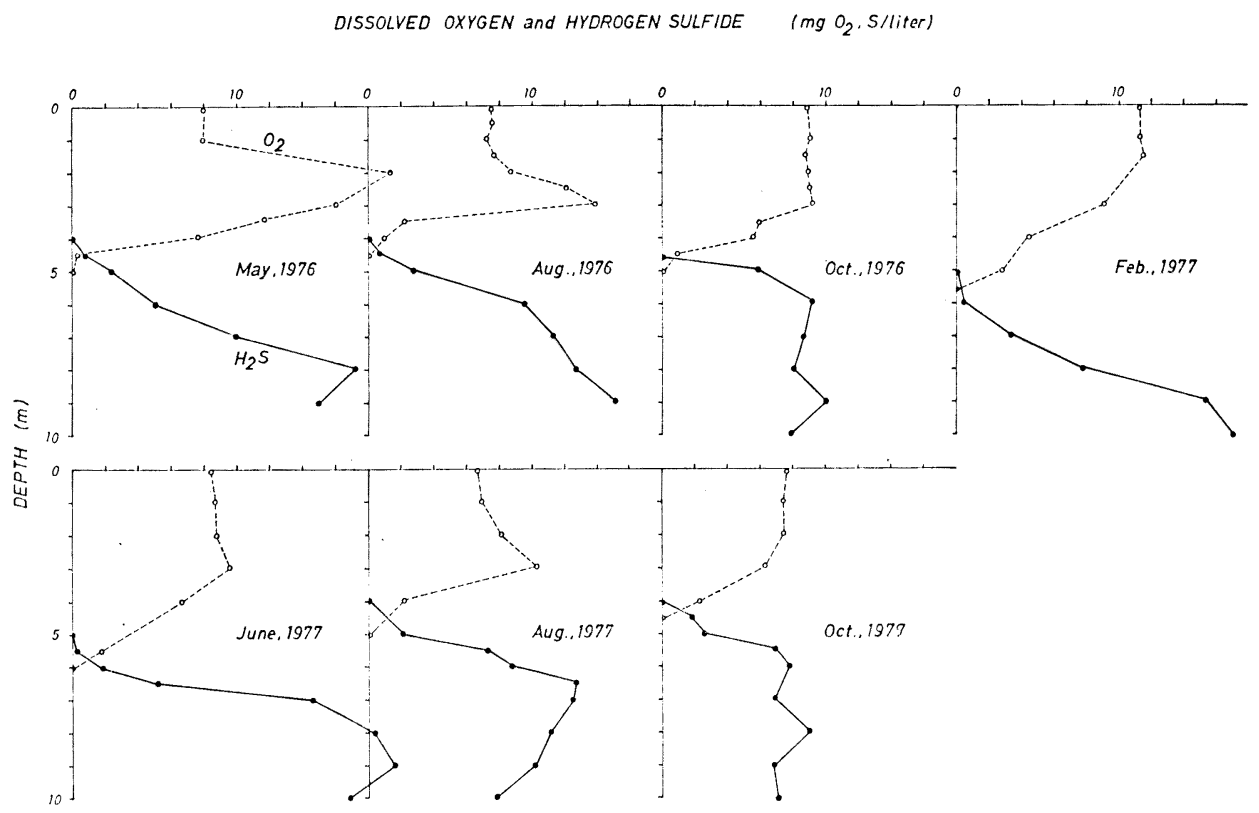

Fig. 6. Vertical distributions of dissolved oxygen and hydrogen sulfide in Lake Kaiike during the period, May, 1976 and October, 1977.

\section{Dissolved oxygen and hydrogen sulfide}

\section{contents}

Figure 6 shows the vertical distributions of amounts of dissolved oxygen and hydrogen sulfide in Lake Kaiike during May, 1976 and October, 1977. Hydrogen sulfide up to $20 \mathrm{mg}^{l^{-1}}$ was found in the near bottom water.

\section{Discussion}

One of the characteristic features of Lake Kaiike is the presence of high temperature water in the halocline of $2-4 \mathrm{~m}$ depth (Fig. 4). In general, vertical water motion in a halocline is minimized due to a stabilizing effect of a vertical density gradient. 
Heat gained in this zone from absorption of the solar radiation cannot readily dissipate, and such a high temperature layer is formed. The halocline acts as an effective barrier for heat transfer.

If the highest temperature of water at various depths observed in summer and the lowest temperature in winter were assumed to represent the highest and lowest heat level of the lake, an annual heat budget of Lake Kaiike $\left(\Theta_{\mathrm{ba}}\right)$, the total amount of heat that enters the lake between the time of its lowest and highest heat contents through the unit surface area of the lake, could be obtained using the equation (HUTCHINSON, 1957);

$$
\Theta_{\mathrm{ba}}=\frac{\rho \mathrm{C}}{\mathrm{A}_{0}} \int_{0}^{z_{\mathrm{m}}} \mathrm{A}_{\mathrm{z}}\left(\theta_{\mathrm{sz}}-\theta_{\mathrm{wz}}\right) \mathrm{d}_{\mathrm{z}}
$$

where $\theta_{\mathrm{sz}}$ and $\theta_{\mathrm{wz}}$ are summer and winter temperature at depth $z, C$ is specific heat of lake water, $\rho$ is specific density of the water, ( $\rho$ C constant through all the depth). $A_{0}$ is the lake surface area, $A_{z}$ is area bounded by contour $z$ and $z_{m}$ is maximum depth. The value of $\Theta_{\mathrm{ba}}$ is estimated to be about $10,000 \mathrm{cal} \mathrm{cm}^{-2}$, which is a little higher than those of subtropical or polar lakes given by Hutchinson (1957).

The second characteristics of Lake Kaiike is the presence of a noticeable amount of hydrogen sulfide in the deeper saline water. Dissolved oxygen vanished at 4-5 $\mathrm{m}$ depth (Fig. 6). Hydrogen sulfide appeared at this depth and it increased downwards. Subsurface maxima of dissolved oxygen were observed in spring and summer. They are probably caused by accumulation of photosynthetically produced oxygen at this layer due to a limited vertical water motion.

These characteristics are thought to be due to the stratified condition of the lake. But the vertical distribution of chlorinity in Lake Kaiike (Fig. 2) suggests that the stratified condition is not entirely stable. In winter there were marked decreases in chlorinity in the middle layer: 5 and $7 \mathrm{~m}$ depths. A similar irregular distribution of chlorinity was also found in March, 1938 (Kobe Marine ObServatory, 1941). This seems to be due to intrusion of upper brackish water to these depths, probably induced by a steady strong wind blowing over the surface during this period. A decrease in chlorinity in the middle layer was also found in October, 1976 (Fig. 3), although it was rather slight compared with that in February. A strong wind was also blowing over the surface at that time. At the middle depth lower chlorinity water spread as a discrete layer from the leeward end of the lake.

From spring to summer, chlorinity of the lower layer showed a marked increase, suggesting that intrusion of seawater into the lake by seepage through the gravel bar occurs during this period. This is probably due to the high sea level during this period (Fig. 2).

Although a significant seasonal change in chlorinity distribution is observed in the lake, no essential difference between the present chlorinity distribution and that in 1934 reported by Kobe MARINe ObSERVATORY (1935) suggests that the lake reaches a long-term equilibrium state with regular seasonal cycles, in which upward transport of seawater by partial destruction of the stratified condition of the lake during autumn and winter is just balanced by seawater intrusion during spring and summer.

\section{Acknowledgments}

The author wishes to express his thanks Profs. H. IRIE and S. IIzUKA of Nagasaki University for their encouragement in the course of the work. The author is much indebted to Mr. K. Nagayama, the head teacher of Kamikoshiki Middle School, and his pupils for their help; the observations of Lake Kaiike in April and July, 1976 were done entirely by them. The author is indebted to Messrs. C. Misumi, I. Maeda, N. Kato and Y. 
Morishige, students of Faculty of Fisheries, Nagasaki University, for their generous assistance in carrying out the observations of the lake. The author's thanks are also due to Mr. K. YanaGi, Director of the Urauchi Fishery Cooperative Association, and to the crew of the Kakusui for their hospitality rendered during the observations.

\section{摘 要}

鹿児島県上苗島の小さな沿岸湖貝池での塩素量, 水 温, 溶存酸素および硫化水素量の 鉛直分布を 1976 年 4 月から翌年 10 月にかけ測定した。貝池（面積： $0.15 \mathrm{~km}^{2}$; 深さ: $11.6 \mathrm{~m}$ ) は上部汽水層（塩素量： $6.6 \sim 12.2 \%$ ）と下部塩水層（塩素量：17\%以上）に より成層している。春から夏にかけ $39^{\circ} \mathrm{C} に も$ 達する 高温部が境界首に出現する。下層は年間を通して無酸 素状態にあり，顕著な量の硫化水素が存在した．秋か ら冬にかけ湖は風による擾乱作用を受け成風状態は幾 分変化した。春から夏にかけ海面の上昇にともない海 水は䃯丘内を渗透し湖底に進入した。

\section{References}

American Public Health Association (1965): Standard methods for the examination of water and wastewater. 12ed., APHA, New York.

Aramaki, M., M. Yamaguchi and Y. Tanaka (1976): A geomorphological and hydrological study on lagoons of Kamikoshiki Island, Japan.
Senshu-shizenkagaku-kiyo, No. 9, 1-80. (in Japanese)

Hutchinson, G.E. (1957) : A treatise on limnology, Vol. 1. John Wiley \& Sons, New York. Kobe Marine Observatory (1935) : Reports of the limnological observations taken in the five small lakes in the Koshiki-zima Islands, Kyushu. J. Oceanogr. (Kobe), 8 : 163-199. (in Japanese)

Kobe Marine Observatory (1941) : Reports of the second and third limnological observations in lakes in the Koshiki-zima Island. $J$. Oceanogr. (Kobe), 13: 286-313. (in Japanese) Maritime Safety Agency of Japan (1976) : 1976 Tide tables. Vol.1. Nippon and its vicinities. Hydrographic Association of Japan, Tokyo, p. 285. (in Japanese)

Maritime Safety Agency of Japan (1977) : 1977 Tide tables. Vol.1. Nippon and its vicinities. Hydrographic Association of Japan, Tokyo, p. 285. (in Japanese)

Matsuyama, M. (1977) : Limnological features of Lake Kaiike, a small coastal lake on Kamikoshiki Island, Kagoshima Prefecture, Japan. Jap. J.Limnol., 38: 9-18.

（著者：松山通郎，長崎大学水産学部，辰崎市文教 町 ; Michiro Matsuyama, Faculty of Fisheries, Nagasaki University, Bunkyo-machi, Nagasaki, 852) 